\title{
MANFAAT PENERAPANSISTEM MANAJEMEN K3 DALAM UPAYA PENCAPAIAN ZERO ACCIDENT DI SUATU PERUSAHAAN
}

\author{
Korneilis ${ }^{1}$, Waliadi Gunawan ${ }^{2}$ \\ Universitas Banten Jaya \\ Serang, Banten 42117 \\ Email:korneilis@unbaja.ac.id ${ }^{1}$,waliadigunawan@unbaja.ac.id ${ }^{2}$
}

\begin{abstract}
Industrial competition that is increasingly stringent requires companies to optimize all of their resources, including human resources, namely workers in producing high quality products. The safety and health of the workers must be considered, which is carried out based on the Occupational Health and Safety Management System (SMK3) applied by the related company. The obligation to implement SMK3 is regulated in Law No. 13 of 2003 concerning manpower. This journal describes how the implementation of SMK3 can be an effort to achieve zero accident. Aspects of sustainability and success of SMK3 are influenced by the following elements, supporting facilities, accident statistics, Hazard Identification \& Risk Assessment (HIRA), Policy, Administration and Organization, Monitoring and Reporting, Motivation, Leadership and Training.
\end{abstract}

Keywords: K3, Management System, SMK3, work accident, zero accident

\section{PENDAHULUAN}

Persaingan industri yang semakin ketat menuntut perusahaan untuk mengoptimalkanseluruh sumber daya yang dimiliki dalammenghasilkan produk berkualitas tinggi. Kualitas produk yang dihasilkan tidak terlepas dari peranan sumber daya manusia (SDM) yang dimiliki perusahaan. Faktor-faktor produksi dalam perusahaan seperti modal, mesin, dan material dapat bermanfaat apabila telah diolah oleh SDM. SDM sebagai tenaga kerja tidak terlepas dari masalah-masalah yang berkaitan dengan keselamatan dan kesehatannya sewaktu bekerja.

Kesehatan dan keselamatan kerja (K3) merupakan salah satu persyaratan untuk meningkatkanproduktivitas kerja karyawan, di samping itu K3 adalah hak asasi setiap tenaga kerja. Di era globalisasi dan pasar bebas Asean Free Trade Ageement (AFTA) dan World Trade Organization (WTO) serta Asia Pacific Ecomoic Community (APEC) yang akan berlaku tahun 2020, dan untuk memenangkan persaingan bebas ternyata 
kesehatan dan keselamatan kerja juga menjadi salah satu persyaratan yang harus dipenuhi oleh industri di Indonesia. SMK3 merupakan konsep pengelolaan K3 secara sistematis dan komprehensif dalam suatu sistem manajemen yang utuh melalui proses perencanaan, penerapan, pengukuran dan pengawasan.

Setiap tahun ribuan kecelakaan terjadi di tempat kerja yang menimbulkan korban jiwa, kerusakan materi, dan gangguan produksi. Pada tahun 2007 menurut jamsostek tercatat 65.474 kecelakaan yang mengakibatkan 1.451 orang meninggal, 5.326 orang cacat tetap dan 58.697 orang cedera. Data kecelakaan tersebut mencakup seluruh perusahaan yang menjadi anggota jamsostek dengan jumlah peserta sekitar 7 juta orang atau sekitar 10\% dari seluruh pekerja di Indonesia. Dengan demikian angka kecelakaan mencapai 930 kejadian untuk setiap 100.000 pekerja setiap tahun. Oleh karena itu jumlah kecelakaan keseluruhannya diperkirakan jauh lebih besar. Bahkan menurut penelitian world economic forum pada tahun 2006, angka kematian akibat kecelakaan di Indonesia mencapai 17-18 untuk setiap 100.000 pekerja.

Berdasarkan data International Labour Organization (ILO) 2003 ditemukan bahwa di Indonesia tingkat pencapaian penerapan kinerja K3 di perusahaan masih sangat rendah, hanya sekitar 2\% (sekitar 317 buah) perusahaan yang telah menerapkan K3. Sisanya sebesar 98\% (sekitar 14.700 buah) perusahaan belum menerapkan K3 secara baik. Data ILO juga menunjukkan bahwa 317 juta kecelakaan kerja terjadi setiap tahunnya dan 6.300 orang meninggal setiap harinya karena kecelakaan kerja. Angka kecelakaan kerja rata-rata per tahun di Indonesia mencapai 99.000 kasus dan 20 diantaranya termasuk fatal, karena menyebabkan korban tewas atau cacat seumur hidup. Menurut data Jamsostek kecelakaan kerja tahun 2007 mencapai 83.741 kasus dan terus meningkat setiap tahun hingga mencapai 99.491 kasus pada tahun 2011.

Masih banyak perusahaan yang tidak menerapkan SMK3 bahkan tidak menjadikan masalah K3 sebagai prioritas utama. Menurut Maulana (2011) hal ini dikarenakan masih ada perusahaan menganggap bahwa semua pengeluaran yang terkait dengan program-program K3 hanya sebagai biaya (costs) yang harus ditanggung, pemborosan dan bukan sebagai investasi untuk melindungi asset-asset (mesin, fasilitas dan infrastruktur produksi, dan SDM). 
Salah satu cara pencegahan kecelakaan kerja yaitu dilakukan melalui penerapan Sistem Manajemen Keselamatan dan Kesehatan Kerja (SMK3). Kewajiban penerapan SMK3 diatur dalam UU No. 13 tahun 2003 pasal 87 ayat 1 tentang ketenagakerjaan yang berisi bahwa "Setiap perusahaan wajib menerapkan Sistem Manajemen Keselamatan dan Kesehatan Kerja (SMK3) yang terintegrasi dengan sistem manajemen perusahaan".Ketentuan mengenai penerapan Sistem Manajemen Keselamatan dan Kesehatan Kerja (SMK3) juga diatur dalam Peraturan Pemerintah Republik Indonesia Nomor 50 Tahun 2012 Pasal 5 Ayat 2 yang menyatakan bahwa "Setiap perusahaan yang mempekerjakan tenaga kerja sebanyak 100 orang atau lebih dan atau mempunyai tingkat potensi bahaya tinggi wajib menerapkan SMK3 di perusahaannya”.

ILO (International Labour Organization) menilai penerapan SMK3 di Indonesia kurang memuaskan, dipaparkan bahwa dari sekitar 15.043 perusahaan skala besar, hanya sekitar 317 perusahaan $(2,1 \%)$ yang menerapkan SMK3. Itu berarti meskipun Indonesia sudah menerapkannya, tetapi masih perlu memperbaiki penerapan SMK3 itu.

Tujuan penelitian ini adalah mengetahui peranan sistem manajemen keselamtan dan kesehatan kerja (K3) dalam upaya pencapaian zero accident di suatu perusahaan.

\section{METODE}

Metode penulisan yang digunakan adalah metode Journal Review, dengan cara menganalisa hasil penelitian dari jurnal-jurnal yang telah ada kemudian menggabungkann hasil penelitian tersebut hingga menjadi satu informasi terpadu mengenai manfaat K3 di perusahaan.

\section{HASIL DAN PEMBAHASAN}

\section{Pengertian Keselamatan dan Kesehatan Kerja}

Kesehatan kerja merupakan suatukondisi kesehatan yang bertujuan agarpekerja memperoleh derajat kesehatansetinggi-tingginya, baik jasmani, rohani,maupun sosial, dengan usahapencegahan dan pengobatan terhadappenyakit atau gangguan kesehatan yangdisebabkan oleh pekerjaan danlingkungan kerja maupun penyakitumum. Sedangkan Keselamatan danKesehatan Kerja adalah suatu pemikiran danupaya untuk 
menjamin keutuhan dan kesempurnaan baik jasmaniah maupun rohaniah tenaga kerja pada khususnya, dan manusia pada umunya, hasil karya dan budaya untuk menuju masyarakatadil dan makmur.

\section{Tujuan Keselamatan dan Kesehatan Kerja}

K3 memiliki beberapa tujuan diantaranya adalah :

a. Agar setiap pegawai mendapatjaminan keselamatan dan kesehatan kerja, baik secara fisik, sosial, maupun psikologis.

b. Agar setiap perlengkapan dan peralatan kerja digunakan sebaik-baiknya

c. Agar semua hasil produksi dipelihara keamanannya

d. Agar ada jaminan atas pemeliharaan dan peningkatan kesehatan gizi pegawai

e. Agar meningkatan kegairahan, keserasian kerja, dan partisipasi kerja

f. Agar terhindar dari gangguan kesehatan yang disebabkan oleh lingkungan atau kondisi kerja

g. Agar setiap pegawai merasa aman dan terlindungi dalam bekerja.

\section{Manfaat Penerapan Keselamatan dan Kesehatan Kerja}

Manfaat penting dalam penerapan K3, yaitu :

a. Perlindungan Karyawan, tujuan inti penerapan sistem manajemen K3 adalah memberi perlindungan kepada pekerja.

b. Memperlihatkan kepatuhan padaPeraturan dan Undang-undang. Perusahaan telah menunjukan itikadbaiknya dalam memenuhi peraturandan perundang-undangan sehingga dapat beroperasi normaltanpa menghadapi kendala dari segiketenagakerjaan.

c. Mengurangi Biaya. Sistem Manajemen K3,dapat mencegah terjadinyakecelakaan, kerusakan, atau sakitakibat kerja, sehingga dapat mengurangi biaya seperti premi asuransi.

d. Membuat sistem menejemen yang efektif:

e. Adanya prosedur yang terdokumentasi maka segala aktivitas dan kegiatan yang terjadi akan terorganisir, terarah dan berada dalam koridor yang teratur. 
f. Meningkatkan kepercayaan dan kepuasan pelanggan :

g. Dengan adanya pengakuan penerapan Sistem Manajemen K3, citra organisasi terhadap kinerjanya akan semakin meningkat, dan tentu ini akan berdampak kepada peningkatan kepercayaan pelanggan.

\section{Langkah-langkah Penerapan K3}

Langkah-langkah yang harus dilakukan dalam penerapan K3 adalah :

a. Pernyataan komitmen dan penetapan kebijakan untuk menerapkan Sistem Manajemen K3 dalam organisasi/manajemen yang harus dilakukan oleh manajemen puncak.

b. Menetapkan cara penerapan Sistem Manajemen K3.

c. Membentuk kelompok kerja penerapan yang terdiri atas wakil dari setiap unit kerja, biasanya manajer unit kerja. Hal ini penting karena merekalah yang tentunya paling bertanggung jawab terhadap unit kerja yang bersangkutan.

d. Menetapkan sumber daya yang diperlukan, mencakup personel / orang, perlengkapan, waktu, dan dana.

e. Kegiatan penyuluhan untuk membangun partisipasi seluruh karyawan perusahaan dalam penerapan Sistem Manajemen K3

f. Peninjauan sistem yang sedang berlangsung untuk dibandingkan dengan persyaratan yang ada dalam Sistem Manajemen K3. Peninjauan ini dapat dilakukan melalui dua cara yakni dengan meninjau dokumen prosedur dan meninjau pelaksanaannya.

g. Penyusunan Jadwal Kegiatan

h. Pengembangan Sistem Manajemen K3 mencakup dokumentasi, pembagian kelompok, penyusunan bagan alir, penulisan manual Sistem Manajemen K3, prosedur dan instruksi kerja.

i. Penerapan sistem dari hasil pengumpulan dan pembuatan dokumen, dan dilakukan pemantauan secara berkalasebelum pelaksanaan audit internal.

j. Proses sertifikasi ke lembaga sertifikasi Sistem Manajemen K3. 


\section{Aspek Keselamatan dan Kesehatan Kerja}

Ada dua aspek yang digunakan untuk mengatasi masalah K3 yaitu Safety Psychology/ penyebab kecelakaan dan Industrial Clinical Psychology/penurunan kinerja karyawan (Miner dalam Ilham, 2002). Faktor-faktor dari kedua aspek tersebut sebagai berikut:

1. Safety Psychology terdiri dari 6 faktor, yaitu:

a. Laporan dan Statistik Kecelakaan yaitu jumlah kecelakaan yang terjadi ditempat kerja untuk mengetahui potensi terjadinya kecelakaan kerja dan cara mengantisipasinya.

b. Pendidikan dan Pelatihan Keselamatanuntuk memberikan pengetahuan tentang keselamatan kerja dan pencegahannya.

c. Publikasi dan Kontes Keselamatan yaitu pemberian informasi dan pesan mengenai keselamatan kerja karyawan berupa spanduk dan poster K3 dengan tujuan utuk selalu memotivasi karyawan.

d. Kontrol terhadap Lingkungan Kerjaadalah pemeriksaan/pengendalian lingkungan kerja untuk melindungi karyawan dari bahaya kecelakaan kerja dan menciptakan lingkungan kerja yang aman dan nyaman.

e. Inspeksi dan Disiplin adalah pengawasan terhadap lingkungan kerja dan perilaku kerja karyawan untuk menjaga agar setiap mesin dan peralatan selalu dalam kondisi aman dan siap untuk digunakan.

f. Peningkatan Kesadaran K3merupakan usaha perusahaan dalam mensukseskan program K3 diperusahaan dan selalu melakukan peningkatan kesadaran penerapan $\mathrm{K} 3$ secara berkesinambungan.

2. Industrial Clinical Psychology terdiri dari dua faktor, yaitu:

a. Konseling untuk meningkatkan kembali semangat kerja karyawan dan mengetahui permasalahan yang dihadapi karyawan selama bekerja.

b. Employee Assistance Program

c. Pembimbingan yang dilakukan secara intensif untuk menangani berbagai macam masalah yang dihadapi karyawan. 


\section{Program Keselamatan dan Kesehatan Kerja}

Program K3 adalah sebuah rencana tindakan yang dirancang untuk mencegah kecelakaan kerja dan PAK dengan program :

1. Menyusun rencana kerja pencegahan dan mengatasi kasus kecelakaan kerja

2. Menyusun organisasi $\mathrm{K} 3$ dan menyediakan alat perlengkapannya

3. Melaksanakan berbagai program termasuk antara lain :

- Menghimpun informasi dan data kasus kecelakaan secara periodik

- Mengidentifikasikan sebab-sebab kasus kecelakaan kerja,

- Menganalisa dampak kecelakaan kerja bagi pekerja sendiri, bagi pengusaha dan bagi masyarakat pada umumnya.

- Merumuskan saran-saran bagi Pemerintah, Pengusaha dan Pekerja untuk menghindari K3

- Memberikan saran mengenai system kompensasi atau santunan bagi mereka yang menderita kecelakaan kerja.

- Merumuskan sistem dan sarana pengawasan, pengamanan lingkungan kerja, pengukuran tingkat bahaya, serta kampanye menumbuhkan kesadaran dan penyuluhan $\mathrm{K} 3$.

4. Melakukan pengawasan program. Prosedur penerapan program K3 perlu dikuasai oleh semua pihak karena ada beberapa faktor yang peru diperhatikan, antara lain:

a. Bahaya pada area kerja dikenali dan dilakukan tindakan pengontrolan yang tepat.

b. Kebijakan yang sah pada tempat kerja dan prosedur pengontrolan risiko diikuti.

c. Tanda bahaya dan peringatan dipatuhi.

d. Pakaian pengamanan digunakan sesuai dengan SI (Standar Internasional).

e. Teknik dan pengangkatan/ pemindahan secara manual dilakukan dengan tepat.

f. Perlengkapan dipilih sebelum melakukan pembersihan dan perawatan secara rutin.

g. Metode yang aman dan benar digunakan untuk pembersihan dan pemeliharaan Perlengkapan

h. Peralatan dan area kerja dibersihkan/ dipelihara sesuai dengan keamanan, jadwal pemeliharaan berkala, tempat penerapan dan spesifikasi pabrik. 
Untuk menentukan apakah suatu strategi efektif atau tidak, perusahaan dapat membandingkan insiden, kegawatan dan frekuensi penyakit-penyakit dan kecelakaan sebelum dan sesudah strategi tersebut diberlakukan. Berikut ini sumber dan strategi untuk meningkatkan keselamatan dan kesehatan kerja menurut Schuler dan Jackson (2009):

Tabel 1. Sumber dan Strategi untuk Meningkatkan Keselamatan dan Kesehatan Kerja (K3)

\begin{tabular}{lll}
\hline No. & Sumber & Strategi \\
\hline
\end{tabular}

1. Lingkungan KerjaFisik

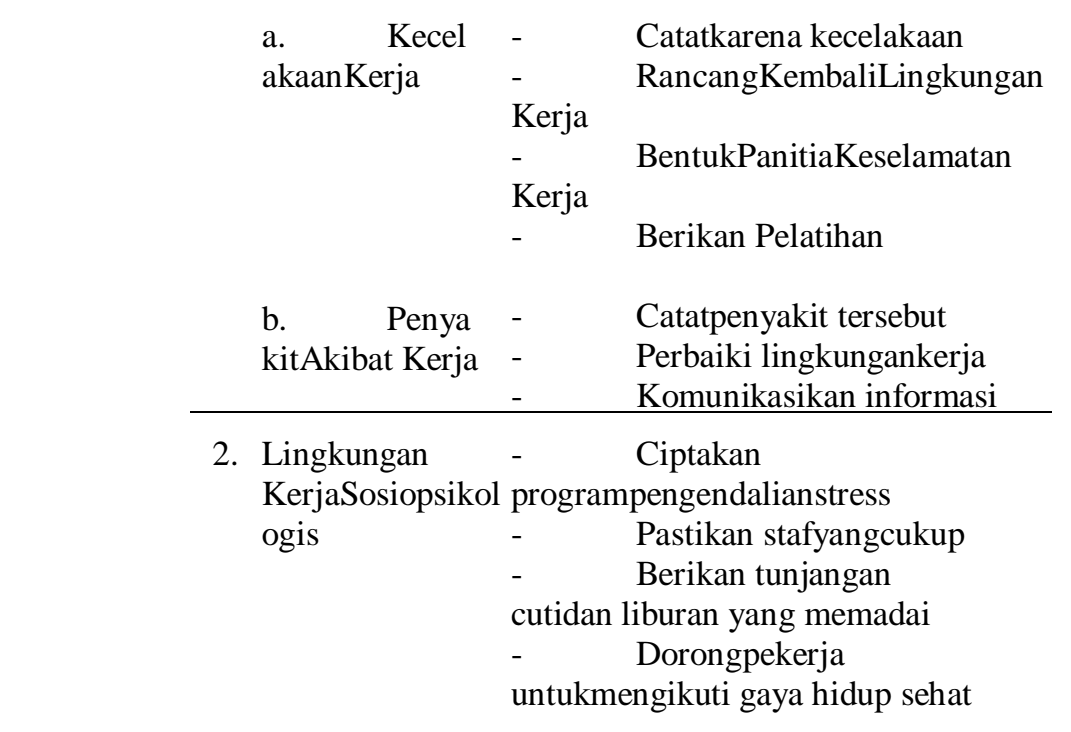

$\overline{\text { Sumber: Schuler, Randall S. dan Susan E. Jackson. } 1999 .}$

Manajemen Sumber DayaManusia Menghadapi Abad Ke-21. Jakarta: Erlangga

\section{Manfaat Program Keselamatan dan Kesehatan Kerja}

Manfaat program K3 apabila dilaksanakan dengan baik adalah sebagai berikut :

1. Meningkatkan produktivitas karena menurunnya jumlah hari kerja yang hilang.

2. Meningkatnya efisiensi dan kualitas pekerja yang lebih komitmen.

3. Menurunnya biaya-biaya kesehatan dan asuransi.

4. Tingkat kompensasi pekerja dan pembayaran langsung yang lebih rendah karena menurunnya pengajuan klaim. 
5. Fleksibilitas dan adaptabilitas yang lebih besar sebagai akibat dari partisipasi dan ras kepemilikan.

6. Rasio seleksi tenaga kerja yang lebih baik karena meningkatkan citra perusahaan.

7. Perusahaan dapat meningkatkan keuntungannya secara substansial.

\section{Faktor Keselamatan Kerja}

Keselamata kerja adalah sarana utama untuk pencegahan kecelakaan, cacat, dan kematian sebagai akibat dari kecelakaan kerja. Keselamatan kerja yang baik adalah pintu gerbang bagi keamanan tenaga kerja. Menurut Suma'mur (1981), tujuan keselamatan kerja adalah:

1. Para pegawai mendapat jaminan keselamatan dan kesehatan kerja.

2. Agar setiap perlengkapan dan peralatan kerja dapat digunakan sebaik-baiknya.

3. Agar semua hasil produksi terpelihara keamanannya.

4. Agar adanya jaminan atas pemeliharaan dan peningkatan gizi pegawai.

5. Agar dapat meningkatkan kegairahan, keserasian dan partisipasi kerja.

6. Terhindar dari gangguan kesehatan yang disebabkan oleh lingkungan kerja.

7. Agar pegawai merasa aman dan terlindungi dalam bekerja.

Syarat-syarat keselamatan kerja yaitu :

a. mencegah dan mengurangi kecelakaan;

b. mencegah, mengurangi dan memadamkan kebakaran;

c. mencegah dan mengurangi bahaya peledakan;

d. memberi kesempatan atau jalan menyelamatkan diri pada waktu kebakaran atau kejadian-kejadian lain yang berbahaya;

e. memberi pertolongan pada kecelakaan;

f. memberi alat-alat perlindungan diri pada para pekerja;

g. mencegah dan mengendalikan timbul atau menyebar luasnya suhu, kelembaban, debu, kotoran, asap, uap, gas, hembusan angin, cuaca, sinar atau radiasi, suara dan getaran;

h. mencegah dan mengendalikan timbulnya penyakit akibat kerja baik physik maupun psychis, peracunan, infeksi dan penularan;

i. memperoleh penerangan yang cukup dan sesuai; 
j. menyelenggarakan suhu dan lembab udara yang baik;

k. menyelenggarakan penyegaran udara yang cukup;

1. memelihara kebersihan, kesehatan dan ketertiban;

m. memperoleh keserasian antara tenaga kerja, alat kerja, lingkungan, cara dan proses kerjanya;

n. mengamankan dan memperlancar pengangkutan orang, binatang, tanaman atau barang;

o. mengamankan dan memelihara segala jenis bangunan;

p. mengamankan dan memperlancar pekerjaan bongkar-muat, perlakuan dan penyimpanan barang;

q. mencegah terkena aliran listrik yang berbahaya;

r. menyeseuaikan dan menyempurnakan pengamanan pada pekerjaan yang bahaya kecelakaannya menjadi bertambah tinggi.

\section{Faktor Kesehatan Kerja}

Kesehatan Kerja adalah suatu usaha yang bertujuan agar pekerja atau masyarakat pekerja memperoleh derajat kesehatan setinggi-tingginya, baik fisik atau mental maupun sosial dengan usaha-usaha preventif dan kuratif terhadap penyakit atau gangguan kesehatan yang diakibatkan faktor-faktor pekerjaan dan lingkungan kerja serta terhadap penyakit-penyakit umum.

Program kesehatan fisik yangdibuatoleh perusahaansebaiknya terdiri dari salah satuataukeseluruhanelemen-elemen berikut ini:

a. Pemeriksaan kesehatan pada waktu karyawan pertama kali diterima bekerja.

b. Pemeriksaan keseluruhan para karyawan kunci (key personal) secara periodik.

c. Pemeriksaan kesehatan secara sukarela untuk semua karyawan secara periodik.

d. Tersedianya peralatan dan staf media yang cukup.

e. Pemberian perhatian yang sistematis yang preventif masalah ketegangan

f. Pemeriksaan sistematis dan periodik terhadap persyaratan-persyaratan sanitasi yang baik. 


\section{Faktor Lingkungan Kerja}

Faktor-faktor yang mempengaruhi terbentuknya suatukondisilingkungankerja dikaitkan dengan kemampuankaryawan adalah :Penerangan, Ukuran ruangan, Pengaturan ruangan, Suhu, Mutu udara, Kebisingan, Keamanan, Kebersihan.

\section{Kecelakaan Kerja}

Kecelakaan kerja adalah suatu kejadian atau peristiwa yang tidak diinginkan yang merugikan terhadap manusia, merusak harta benda atau kerugian terhadap proses.

Faktor penyebab terjadinya kecelakan kerja dapat dilihat dari berbagai sudut, diantaranya:

1. Kebijakan pemerintah (Undang-undang, Peraturan Pemerintah, serta Pengendalian \& tindakan hukum)

2. Kondisi pekerjaan yang dilakukan karyawan dalam suatu perusahaan

a. Standar kerja yang kurang tepat dan pelaksanaanya juga tidak tepat.

b. Jenis pekerjaan fisik yang sangat berbahaya. Namun di sisi lain, fasilitas keselamatan kerja sangat kurang.

c. Kenyamanan kerja yang sangat kurang karena kurang tersedianya unsur pendukung keselamatan dan kenyamanan kerja.

d. Tidak tersedianya prosedur manual petunjuk kerja.

e. Kurangnya kontrol, evaluasi, dan pemeliharaan tentang alat-alat kerja secara rutin.

3. Kondisi karyawan

a. Keterampilan karyawan dalam hal K3 yang rendah.

b. Kondisi kesehatan fisik karyawan yang tidak prima.

c. Kondisi kesehatan mental, seperti rendahnya motivasi tentang K3 serta tingginya derajat stres dan depresi.

d. Kecanduan merokok, minuman keras, dan narkoba.

4. Kondisi fasilitas perusahaan

a. Ketersediaan fasilitas yang kurang cukup (jumlah dan mutu).

b. Kondisi ruangan kerja yang kurang nyaman.

c. Tidak tersedianya fasilitas kesehatan dan klinik perusahaan.

d. Tidak tersedianya fasilitas asuransi kecelakaan. 
e. Kurangnya pelatihan dan sosialisasi tentang pentingnya keselamatan kerja di kalangan karyawan.

Berdasarkan hasil penelitian Syamsudin (2008) dan Muhammad Iqbal Fathoni (2008), menunjukkan bahwa dari jumlah kecelakaan kerja yang terjadi, secara umum dapat diklasifikasikan bahwa kecelakaan yang disebabkan oleh kesalahan manusia (unsafe action) sebesar 78\%, yang disebabkan kondisi berbahaya dari peralatan (unsafe condition) sebesar 20\%, dan faktor lainnya sebesar 2\%. Hasil penelitian itu membuktikan bahwa perilaku manusia merupakan penyebab utama terjadinya kecelakaan di tempat kerja. Padahal, kecelakaan kerja yang terjadi dapat mengakibatkan korban jiwa, cacat, kerusakan peralatan, menurunnya mutu dan hasil produk, terhentinya proses produksi dan kerusakan lingkungan, yang pada akhirnya akan merugikan semua pihak. Dalam skala besar, akibat kecelakaan kerja yang banyak terjadi dan besarnya jumlah kerugian yang diderita perusahaan, secara kumulatif akan pula merugikan perekonomian sosial.

\section{Zero Accident}

\section{Defenisi Zero Accident}

Penghargaan kecelakaan nihil adalah tanda penghargaan keselamatan dan kesehatan kerja yang diberikan pemerintah kepada manajemen perusahaan yang telah berhasil dalam melaksanakan program keselamatan dan kesehatan kerja sehingga mencapai nihil kecelakaan kerja pada jangka waktu tertentu.

Kecelakaan nihil adalah suatu kondisi tidak terjadi kecelakaan di tempat kerja yang mengakibatkan pekerja sementara tidak mampu bekerja (STMB) selama 2 x 24 jam, menyebabkan terhentinya proses dan atau rusaknya peralatan tanpa korban jiwa dimana kehilangan waktu kerja tidak melebihi shift berikutnya pada kurun waktu tertentu dan jumlah jam kerja orang tertentu.

\section{Tata cara untuk memperoleh Kecelakaan kerja nihil (Zero Accident)}

Setiap perusahaan yang telah memenuhi persyaratan untuk memperoleh penghargaan kecelakaan nihil, dapat mengajukan permohonan kepada instansi yang bertanggung jawab di bidang ketenagakerjaan di Kabupaten/Kota dengan disertai data pendukung sebagai berikut: 
1. Jumlah jam kerja nyata seluruh tenaga kerja yang ada di lokasi perusahaan selama 3 (tiga) tahun berturut-turut dan diperinci dalam jumlah jam kerja nyata tahunan;

2. Jumlah jam kerja lembur nyata setiap tenaga kerja, yang bekerja lembur selama 3 (tiga) tahun berturut-turut dan diperinci dalam jumlah jam kerja tahunan;

3. Jumlah jam kerja nyata dari seluruh tenaga kerja pada kontraktor dan atau sub kontraktor (jika ada dan dianggap merupakan bagian dari perusahaan) yang ada di lokasi perusahaan selama 3 (tiga) tahun berturut-turut dan diperinci dalam jumlah jam kerja tahunan;

4. Jumlah jam kerja lembur nyata dari seluruh tenaga kerja kontraktor dan atau sub kontraktor (jika ada dan dianggap merupakan bagian dari perusahaan) yang ada di lokasi perusahaan selama 3 (tiga) tahun berturut-turut dan diperinci dalam jumlah jam kerja tahunan.

\section{Kriteria penilaian penghargaan Kecelakaan Nihil}

Kecelakaan Nihil diberikan kepada perusahaan berdasarkan pengelompokan:

a. Jumlah tenaga kerja

1) Lebih dari 100 orang sebagai kelompok perusahaan besar;

2) 50 - 100 orang sebagai kelompok perusahaan menengah;

3) Sampai dengan 49 orang sebagai kelompok perusahaan kecil.

b. Sektor usaha berdasarkan klasifikasi lapangan usaha Indonesia (KLUI) dan bobot resiko bahaya sesuai dengan penjelasan pasal 2 ayat (1) Undang-undang Nomor 1 tahun 1970 tentang Keselamatan Kerja yaitu 5 variabel potensi bahaya yang terdiri dari:

1) Mesin-mesin, pesawat-pesawat, alat-alat kerja, peralatan lainnya, bahan-bahan dan sebagainya;

2) Lingkungan;

3) Sifat pekerjaan;

4) Cara kerja;

5) Proses produksi.

Zero Accident adalah mengeleminasi semua kecelakaan yang terjadi pada site konstruksi (debraw, 2004) zero accident itu terdiri dari : 
1) Semua luka-luka dan kecelakaan akibat pekerjaan dapat dicegah

2) Tidak adanya perawatan dokter

3) Tidak terjadinya kehilangan hari kerja lost time injury $(\mathrm{LTI}=0)$

4) Tidak adanya perawatan dokter

5) Insidenn ringan maksimal 15 dalam waktu 6 bulan

6) Di dalam proyek konnstruksi pekkerja tidak mengalami cacat permanen

Menurut penelitian terbaru construction industry Institute, yang mensurvei 400 perusahaan konstruksi, kontraktor akan memiliki catatan keamanan yang lebih baik jika:

1) Adanya kenaikan gaji berdasarkan kinera keselamatan

2) Adanya dokumentasi untuk mempelajari kesalahan dari suatu metode keselamatan

3) Survei tentang persepsi keselamatan agar pekerja dapat melakukan cara yang aman pada proyek

4) Pelatihan formal

Dalam penerapann Zero Accident diperusahaan, MPS KUD Tani Mulyo meraih penghargaan zero accident dari tahun 2003 s/d 2011 dengan menerapkan kebijakan K3 sebagai berikut :

(a) Komitmen dengan kebijakan K3 sesuai dengan Permenaker Nomor 05 Tahun 1996.

(b) Elemen sumber daya, dengan telah menepatkan organisasi K3 (P2K3) pada posisi yang dapat menentukan keputusan perusahaan.

(c) Elemen komunikasi dan kepedulian, yaitu berperilaku aman dan dengan menerapkan sistem hadiah dan hukuman dalam penerapan $\mathrm{K} 3$.

(d) Elemen pelatihan dan kompetensi, melaksanakan pelatihan secara internal dan eksternal untuk meningkatkan kompetensi personel dalam bidang K3.

(e) Elemen tugas dan wewenang, menetapkan personel yang mempunyai tanggung jawab dan wewenang yang jelas.

\section{Sistem Manajemen K3}

Sistem ManajemenKeselamatan dan Kesehatan Kerja yang selanjutnya disingkat SMK3 adalah bagian dari sistem manajemen perusahaan secara keseluruhan dalam 
rangka pengendalian risiko yang berkaitan dengan kegiatan kerja guna terciptanya tempat kerja yang aman, efisien dan produktif

Kegagalan manajemen merupakan salah faktor yang dapat menyebabkan terjadinya kecelakaan, seperti dalam teori kecelakaan oleh Bird dan Loftus. Banyak perusahaan yang sudah menerapkan berbagai sistem manajemen untukmeningkatkan kualitas, produktifitas serta menghilangkan potensi terjadinya kerugian akibat kecelakaan dan berhasil mencapai sasaran yang diharapkan dengan menerapkan berbagai sistem manajemen tersebut. Namun tidak jarang pula perusahaan gagal mencapai tujuan dari penerapan sistem manajemen ini. Dalam hal ini banyak faktor dan kendala yang dapat menyebabkan kegagalan manajemen sehingga tujuan penerapan tidak tercapai. Dalam pelaksanaan sistem manajemen K3 ada 3 sasaran yang ingin dicapai perusahaan, diantaranya :

1. Penurunan jumlah masalah terkait $\mathrm{K} 3$, dengan indikatornya yaitu jumlah karyawan yang mengalami kecelakaan kerja dan yang tidak masuk karena sakit.

2. Peningkatan efektivitas penanganan resiko $\mathrm{K} 3$, dengan indikator berupa waktu respon penanganan resiko, jumlah presentase resiko yang ditangani dibanding resiko yang teridentifikasi, dan frekuensi indentifikasi resiko K3 yang dilakukan.

Adapun usaha yang dilakukan dalam menjalankan Sistem Manajemen K3 di perusahaan, mencakup hal-hal berikut:

1. Manajemen Kesehatan dan Keselamatan

Pengelolaan data kesehatan saat ini sudah berkembang dan sistem yang mempermudahnya juga telah ditemukan. Banyak perusahaan yang telah menunjukkan komitmennya terhadap kesehatan pekerja, dilihat dari pemberian asuransi kesehatan kepada pekerjanya, sehingga dapat meningkatkan kepercayaan diri pekerja dalam bekerja dan meningkatkan produktivitas.

Namun dalam manajemen keselamatan, terlihat masih banyak perusahaan yang sulit mencapai zero accident atau tidak ada kecelakaan kerja. Alasan utama dari rendahnya tingkat keselamatan adalah rendahnya tingkat kesadaran akan keselamatan dalam suatu organisasi, selain itu fasilitas keselamatan yang tidak 
memenuhi ketentuan, juga memainkan peranan penting atas terjadinya kecelakaan kerja.

2. Fasilitas Pendukung, Fasilitas tempat cuci dan kamar mandi, kotak P3K, dan maupun fasilitas tempat duduk, dipertimbangkan aspek kebersihan, kelayakan, maupun jumlahnya.

3. Motivasi, Kepemimpinan dan Pelatihan

4. Motivasi, sifat dan jiwa kepemimpinan, serta pelatihan, bergantung pada diri tiap individu. Namun manajemen sumber daya perusahaan dapat meningkatkan nilai dari ketiga aspek tersebut dalam diri karyawan. Dimana usaha pemberian reward \&punishment yang dirasa mampu memberikan sedikit motivasi dalam diri pekerja untuk bekerja lebih giat dan aman, pembinaan mental yang diberikan untuk menumbuhkan jiwa kepemimpinan, dan pelatihan-pelatihan untuk menunjang keahlian yang diperlukan pekerja di bidang kerjanya.

5. Statistik Kecelakaan

Penggunaan statistik kecelakaan dalam sistmen manajemen K3, bermanfaat dalam memberikan gambaran penyusunan kegiatan pengendalian bahaya mapun resiko terjadinya kecelakaan, sehingga kegiatan evaluasi dapat mencapai sasaran secara tepat. Dengan adanya statistik ini, menunjukkan sejauh mana sistem manajemen K3 mempengaruhi tingkat angka kecelakaan suatu perusahaan, dan dapat dinilai pula keefektifan dari sistem tersebut.

6. Hazard Identification \& Risk Assesment (HIRA)

Identifikasi bahaya dan analisa resiko dapat memberikan arahan pengendalian yang perlu dilakukan oleh perusahaan. Upaya ini sanggup mengurangi bahaya di dindustri dan dapat memberikan kondisi lingkungan kerja yang lebih baik bagi para pekerja, sehingga pekerja merasakan bebas dalam bekerja dengan kepercayaan diri dan tanpa rasa takut.

7. Kebijakan, Administrasi dan Organisasi

Sistem kebijakan, administrasi, dan sistem organisasi merupakan tonggak kekuatan/ tulang punggung atas sistem manajemen K3 yang kuat dalam perusahaan. Keberadaan ketiganya mempengaruhi segala aspek yang ada dalam SMK3. 


\section{Pemantauan, dan Pelaporan}

Kegiatan pemantauan dan pelaporan K3 yang dilakukan menghasilkan sekumpulan data yang menunjukkan seberapa jauh upaya yang telah dilakukan suatu perusahaan/industri untuk mencapai zero accident di lingkungannya. Bila terjadi penurunan angka, maka dapat dikatakan bahwa sistem manajemen K3 yang diterapkan di perusahaan tersebut sudah baik, namun bila terjadi sebaliknya maka perlu dilakukannya tinjauan dan kajian ulang terkait SMK3 tersebut Pada umumnya, pelaporan ini dibuat bulanan, triwulan maupun tahunan.

Berdasarkan hasil penelitian $\mathrm{H}$ Abdul Zubar mengatakan bahwa sebagian besar industri/perusahaan dinilai kurang dalam sistem manajemen K3. Pemeliharaan dan penerapan sistem manajemen K3 yang baik sangat diperlukan untuk meningkatkan standar keselamatan di industri. Perlunya dorongan berupa komitmen dari manajemen tingkat atas untuk memperbaiki kondisi yang ada, dan komunikasi yang baik antara manajemen dan pekerja dirasa membantu dalam penerapan K3 perusahaan.

\section{Tantangan dalam Manajemen K3}

Dewasa ini muncul tantangan yang hampir dihadapi semua bidang, termasuknya K3. Tantangan tersebut berupa tantangan teknologi yang mengharuskan K3 mengembangkan sistem manajemennya agar mampu mengikuti arus perkembangan di dunia maupun perusahaan. Laju perubahan teknologi yang cepat harus segera diatasi dengan keahlian teknis untuk mengatasi resiko terkait perubahan tersebut, karena kemungkinan munculnya bahaya dan resiko baru dapat tercipta, seperti ketergantungan akan sistem informasi, kesalahan/kehilangan data maupun informasi, digitalisasi dan bentuk/susunan organisasi baru.Bahkan mampu mengubah perspektif tentang peristiwa atas terjadinya kecelakaan/insiden, perubahan dalam teknik, teknologi \& keterampilan yang digunakan di tempat kerja mengharuskan para pekerja memiliki tingkat keterampilan yang sangat tinggi atau sebaliknya (bergantung pada pengaplikasian teknologi di alur perusahaan). Dengan adanya penyesuaian yang dialami perusahaan dan terutama pekerja, maka dapat mempengaruhi kondisi kesehatan pekerja baik fisik maupun psikis, serta pekerja dapat saja menghiraukan aspek keselamatan kerja mereka.Implementasi sistem manajemen K3 sangat penting dalam memastikan kondisi 
kinerja keselamatan yang baik. Tidak hanya mengurangi angka kecelakaan, tapi juga menjadi salah satu cara untuk mengendalikan waktu, biaya dan kualitas konstruksi.

\section{Pendekatan Sistem Manajemen K3}

Masalah keselamatan mengganggu proses kerja di perusahaan. Dengan pendekatan yang baik dan tepat dalam manajemen K3 dapat mempengaruhi kualitas dan produktivitas kerja. Pekerja tertentu dituntut untuk dapat menciptakan suatu layanan K3 yang dapat digunakan untuk melawan potensi bahaya di tempat kerja. ${ }^{(22)}$ Pendekatan yang dilakukan untuk keselamatan dan kesehatan kerja yang lebih baik terdiri atas antisipasi dan perencanaan penanganan yang tepat terhadap masalah yang dihadapi perusahaan dalam hal keselamatan. Diagnosa masalah yang tepat memungkinkan untuk mengatur kegiatan perusahaan seperti mengalihkan tanggung jawab kepada pihak maupun perusahaan yang kompeten untuk menangani hal tertentu (misal inspuktur kesehatan dan keselamatan/ P2K3). Pengontrolan kegiatan kerja yang dilakukan dengan inspektur K3 dapat memungkinkan adanya perbaikan berkelanjutan dengan sasaran yang lebih tepat.

\section{Menciptakan Budaya K3}

Terdapat beberapa tugas yang dilakukan dalam menciptakan budaya K3 di suatu perusahaan, diantaranya:

1. Persiapan dan penyajian Hazard Identification \& Risk Assessment (HIRA) secara berkala.

2. Mengenalkan dan mempresentasikan kepada karyawan mengenai syarat ergonomi dan keselamatan di perusahaan

3. Partisipasi dalam penentuan keadaan bahaya kecelakaan di tempat kerja dan pembuatan penilaian resiko terkait pekerjaan yang dilakukan

4. Melakukan kerjasama dengan laboratorium berwenang dan terakreditasi untuk melakukan tes dan pengukuran faktor-faktor bahaya di wilayah kerja perusahaan.

5. Seluruh pekerja di perusahaan baik tingkat bawah maupun atas harus paham dan mampu mencegah bahaya, menilai bahaya, dan memerangi sumber-sumber bahaya. 
Jurnal Sistem Informasi dan Informatika (SIMIKA)

Vol.1 Nol tahun 2018

\section{KESIMPULAN}

Manfaat penting dalampenerapan K3, yaitu Perlindungan Karyawan, kepatuhan pada Peraturan dan Undang-undang, Mengurangi Biaya, Membuat sistem menejemen yang efektif, Meningkatkan kepercayaan dan kepuasan pelanggan. agar setiap pegawai mendapatjaminan keselamatan dan kesehatan kerja, baik secara fisik, sosial, maupun psikologis, agar setiap perlengkapan dan peralatan kerja digunakan sebaik-baiknya, agar semua hasil produksi dipelihara keamanannya, agar ada jaminan atas pemeliharaan dan peningkatan kesehatan gizi pegawai, agar meningkatan kegairahan, keserasian kerja, dan partisipasi kerja, agar terhindar dari gangguan kesehatan yang disebabkan oleh lingkungan atau kondisi kerja, agar setiap pegawai merasa aman dan terlindungi dalam bekerja.

Aspek keberlangsungan dan keberhasilan SMK3 dipengaruhi oleh unsur-unsur berikut, fasilitas pendukung, statistik kecelakaan, Hazard Identification \& Risk Assessment (HIRA), Kebijakan, administrasi dan Organisasi, Pemantauan, dan Pelaporan, Motivasi, Kepemimpinan dan Pelatihan.

\section{DAFTAR PUSTAKA}

Arianto, Bayu. Perancangan Sistem Informasi Keselamatan dan Kesehatan Kerja Berbasis WEB.

Artur Woźny, et al. Occupational health and safety management with the use of brainstorming method. Production Engineering Archives 17 (2017) 18-23.

H Abdul Zubar, et al. Occupational Health and Safety Management in Manufacturing Industries. Journal of Scientific \& Industrial Research. Vol 73, June 2014, pp. 381-386.

Hartatik, IP. Buku Praktis Mengembangkan SDM. Yogyakarta : Laksana, 2004.

Heidjrachman, \& Husnan Suad. Manajemen Personalia. Yogyakarta : BPFE, 2006.

International Labour Organization, (ILO). Keselamatan dan Kesehatan Kerja, Sarana Untuk Produktivitas. Jakarta : International Labour Organization (ILO), 2013.

Katlyn, Barbara; Sihombing, Lukas Beladi. Optimization Model of Risk Mitigation in Improving The Performance of Safety Construction in Indonesia. International Symposium on Business and Management - Fall Session. 2014.

Kementrian Tenaga Kerja, \& Transmigrasi. Peraturan Menteri Tenaga Kerja Dan Transmigrasi Nomor 01 Tahun 2007 Tentang Pedoman Pemberian Penghargaan Keselamatan Dan Kesehatan Kerja (K3). Jakarta : s.n., 2007. 
Mangkuprawira, S. dan Vitayala. Manajemen Mutu Sumber Daya Manusia. Jakarta: Ghalia Indonesia, 2007.

Manikam Pillay. Advancing Organisational Health and Safety Management: Are we Learning the Right Lessons?. Conference Paper in Advances in Intelligent Systems and Computing · July 2018.

Maulana, dkk. Evaluasi dan Perbaikan Sistem Manajemen Keselamatan dan Kesehatan Kerja (SMK3) untuk Menekan Unsafe Behavior Pekerja (Studi Kasus PT.DPS), Skripsi. Jurusan Tekik Industri Institut Teknologi Sepuluh Nopember (ITS), Surabaya; 2011.

Merpaung, Junita. Presepsi Tenaga Kerja Tentang Sistem Manajemen Kesehatan dan Keselamatan Kerja (SMK3) dan Pedoman Penerapan SMK3 Di PT. Inalum Kuala Tanjung Tahun 2005. Skripsi. Fakultas Kesehatan Masyarakat Universitas Sumatera Utara, Medan;2005.

Noer Rafikah, Zulyanti. Komitmen Kebijakan Keselamatan Dan Kesehatan Kerja (K3) Sebagai Upaya Perlindungan Terhadap Tenaga Kerja di MPS KUD Tani Mulyo Lamongan. Skripsi. Fakultas Ilmu Sosial dan Ilmu Politik, Universitas 17 Agustus 1945, Surabaya; 2013.

OHSAS 18001. Prosiding Seminar Nasional Teknologi Pengelolaan Limbah XIII. 299304. ISSN 1410-6086.

Peraturan Pemerintah Nomor 50 Tahun 2012 tentang Sistem Manajemen Keselamatan dan Kesehatan Kerja.

Ramli, Soehatman. Sistem Manajemen Keselamatan \& Kesehatan Kerja OHSAS 18001. Jakarta : Dian Rakyat, 2005.

Schuler, Randall S. dan Susan E. Jackson. Manajemen Sumber Daya Manusia Menghadapi Abad Ke-21. Jakarta : s.n., 1999.

Sedarmayanti. Sumber Daya Manusia dan Produktivitas Kerja. Bandung : PT. Mandar Maju, 2009.

Suardi, Rudi. Sistem Manajemen Keselamatan dan Kesehatan Kerja. Jakarta: PPM, 2005.

Suma'mur, P.K. Hygiene perusahaan dan kesehatan kerja. Jakarta : PT. Gunung Agung, 1984.

Undang-undang No 1 Tahun 1970 tentang Keselamatan Kerja.

Zeng S X, Tam V W Y \& Tam C M, Towards occupational health and safety systems in the construction industry of China, Safety Sci 46 (2008) 1155-1168.

Ulewicz R., Klimecka-Tatar D. Mazur M. Niciejewska M. 2015. 